\title{
Relationships between the evaporative stress index and winter wheat and spring barley yield anomalies in the Czech Republic
}

\author{
Martha C. Anderson ${ }^{1, *}$, Christopher R. Hain ${ }^{2}$, Frantisek Jurecka ${ }^{3}$, Miroslav Trnka ${ }^{3}$, \\ Petr Hlavinka ${ }^{3}$, Wayne Dulaney ${ }^{1}$, Jason A. Otkin ${ }^{4}$, David Johnson ${ }^{5}$, Feng Gao ${ }^{1}$ \\ ${ }^{1}$ Hydrology and Remote Sensing Laboratory, USDA-ARS, Beltsville, MD 20705, USA \\ ${ }^{2}$ Earth System Science Interdisciplinary Center, University of Maryland, College Park, MD 20742, USA \\ ${ }^{3}$ Department of Agrosystems and Bioclimatology, Mendel University, 61300 Brno, Czech Republic \\ ${ }^{4}$ University of Wisconsin-Madison, Madison, WI 53706, USA \\ ${ }^{5}$ USDA National Agricultural Statistics Service, Fairfax, VA 22030, USA
}

\begin{abstract}
There is a growing demand for timely, spatially distributed information regarding crop condition and water use to inform agricultural decision making and yield forecasting efforts. Thermal infrared remote sensing of land-surface temperature has proven valuable for mapping evapotranspiration (ET) and crop stress from field to global scales using energy balance models. This is because canopy temperature is strongly regulated by the transpiration flux, which is reduced under stress conditions. This study investigates the utility of an evaporative stress index (ESI), computed using the thermal-based Atmosphere-Land Exchange Inverse (ALEXI) surface energy balance model, for explaining yield variability over the Czech Republic for the period 2002-2014. ESI timeseries, representing standardized anomalies in the actual-to-reference ET ratio and an indicator of vegetation health, are compared with yield data collected for winter wheat and spring barley crops in 32 agricultural districts, comprising a range of climatic conditions within the Czech Republic. Correlations between ESI and yield anomalies vary with climatic region, with strongest correlations identified in the more drought-prone South Moravian districts and weaker relationships in the wetter highlands regions. In most regions, correlations with spring barley yield anomalies exceeded performance for winter wheat. For both crops, correlations peaked during the 1 to 2 mo period prior to the nominal harvest date. These results provide guidance for effective integration of remotely sensed moisture stress indicators within operational yield forecasting systems.
\end{abstract}

KEY WORDS: Evapotranspiration $\cdot$ Drought $\cdot$ Agriculture $\cdot$ Remote sensing $\cdot$ Crop yields $\cdot$ Czech Republic

\section{INTRODUCTION}

Remote sensing indicators are now widely used in agriculture for monitoring crop condition and forecasting yield (Wardlow et al. 2012, Basso et al. 2013, Rembold et al. 2013). Prominent indicators include empirical vegetation indices, such as the normalized

\footnotetext{
${ }^{*}$ Corresponding author: martha.anderson@ars.usda.gov
}

difference vegetation index (NDVI) and the enhanced vegetation index (EVI), which track crop progress and evolution in green biomass amount (Kogan et al. 2003, Mkhabela et al. 2005, 2011, Becker-Reshef et al. 2010, Esquerdo et al. 2011, Fernandes et al. 2011, Gusso et al. 2013, Kouadio et al. 2014). Other more physically based vegetation

(C) The authors 2016. Open Access under Creative Commons by Attribution Licence. Use, distribution and reproduction are unrestricted. Authors and original publication must be credited. 
indices describe light-harvesting capacity or photosynthetic rates, including the leaf area index (LAI), the fraction of absorbed photosynthetically active radiation (fAPAR), or fluorescence spectral features (Lobell et al. 2002, Doraiswamy et al. 2005, Zhang et al. 2005, Rizzi \& Rudorff 2007, López-Lozano et al. 2015, Guan et al. 2016). Other remote sensing indicators reflect various aspects of the surface moisture status, i.e. water supply measured as rainfall, water storage in the soil profile and groundwater retrieved using microwave radiometers or gravimetry, and plant water use assessed via satellite-based estimates of evapotranspiration (ET) (Anderson et al. 2007, Bolten et al. 2010, AghaKouchak \& Nakhjiri 2012, Houborg et al. 2012).

Many studies have investigated correlations between satellite indices and crop yields, with the goal of identifying robust advance indicators of yield anomalies at harvest (e.g. Unganai \& Kogan 1998, Bastiaanssen \& Ali 2003, Johnson 2014, Anderson et al. 2016). These combined studies have demonstrated that no single indicator prevails always and everywhere, with relative performance depending on climate, soils, management, crop type, and growing season, as well as specific sensor limitations. For this reason, multi-indicator approaches have emerged to support operational drought and yield monitoring efforts (e.g. Bastiaanssen \& Ali 2003, Doraiswamy et al. 2007, Anderson et al. 2012b, Johnson 2014). To support these new approaches, we need to better understand the major drivers of yield correlation variability for different indices in order to be able to optimally combine available satellite assets.

This study focuses on the behavior of the evaporative stress index (ESI), an indicator of agricultural drought expressed as standardized anomalies in the ratio of actual-to-potential ET as retrieved using a land surface temperature (LST) based energy balance algorithm (Anderson et al. 2011, 2013, 2015). ET estimates based on LST have the advantage of being more sensitive to variations in both soil surface and root-zone moisture content in comparison with simpler crop coefficient techniques (Anderson et al. 2012a). LST contains thermal signals of both plant stress and soil moisture deficiency, with elevated canopy and soil temperatures resulting from decreased transpiration and soil evaporation fluxes (Moran 2003). Thermal infrared (TIR) retrievals of LST can provide moisture information at smaller spatial scales than are currently accessible through microwave remote sensing, enabling mapping down to sub-field scales (Anderson et al. 2012a). In addi- tion, studies have demonstrated that LST-based ET estimates often provide earlier warning of declining vegetation health than do standard reflectancebased vegetation indices, particularly during rapid drought onset events (Otkin et al. 2013, 2014, 2015, 2016).

Anderson et al. (2016) evaluated the performance of ESI as an indicator of agricultural drought in Brazil, using yield data collected at both the state and municipal levels as a metric of drought impact. ESI showed advantages over LAI and precipitation anomalies, particularly in response to rapidly changing moisture conditions in northeast and southern Brazil. The variability in ESI correlations with yield anomalies over the country was found to be strongly related to local volatility in yield, with lower performance in states showing low year-to-year variability in yield due to more stable growing conditions and rainfall. In some cases, excess moisture can lead to yield reductions, e.g. due to waterlogging or moisture-favoring pests and diseases. Changes in crop management and technology over the period of analysis can further confound correlation analyses.

In this study, factors influencing ESI-yield correlations are investigated using yield data collected at the district scale from 2002 to 2014 in several agricultural regions within the Czech Republic (CR), which span a range in growing conditions related to local climate and elevation. The study compares ESI performance for 2 important cereal crops in Czech agricultural production: winter wheat and spring barley. These crops together comprise the highest planted acreage in field crops in the $\mathrm{CR}$, and encapture different growing seasons (winter vs. spring), which expose the crops to different seasonal impacts in terms of timing and strength of moisture sensitivities (Hlavinka et al. 2009, Trnka et al. 2012).

\section{MATERIALS AND METHODS}

\subsection{Study area}

The study area in the CR is outlined in Fig. 1, along with maps of relevant physical characteristics of the region including elevation and cropping intensity. The districts analyzed in the study (listed in Table 1 and delineated in Fig. 1a) were selected because they had a full record of annual yields for both winter wheat and spring barley over the study period. These districts lie within the regions of Central, South and Northeast Bohemia (STC, JHC, and HKK, respectively), South Moravia (JHM), Northwest and Central 


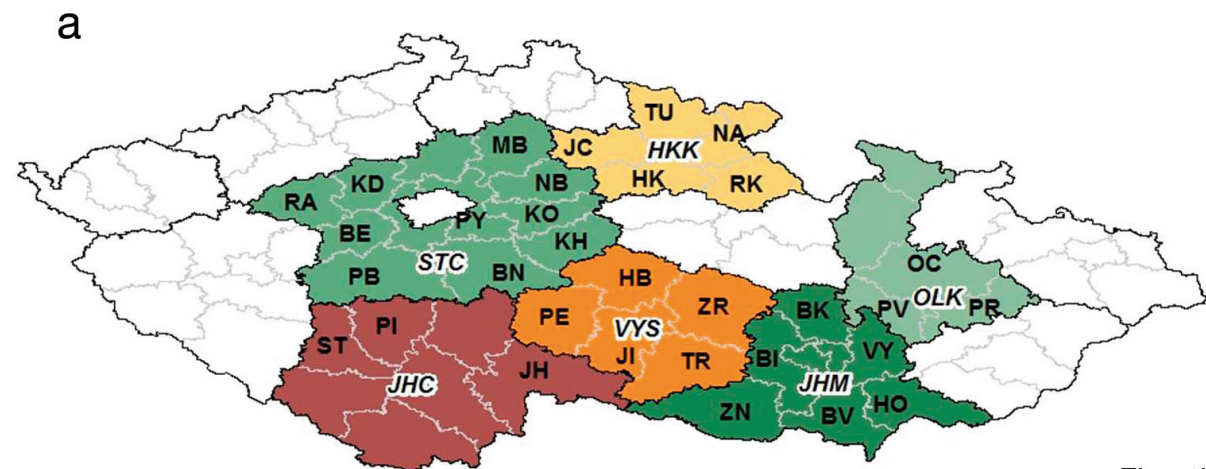

b
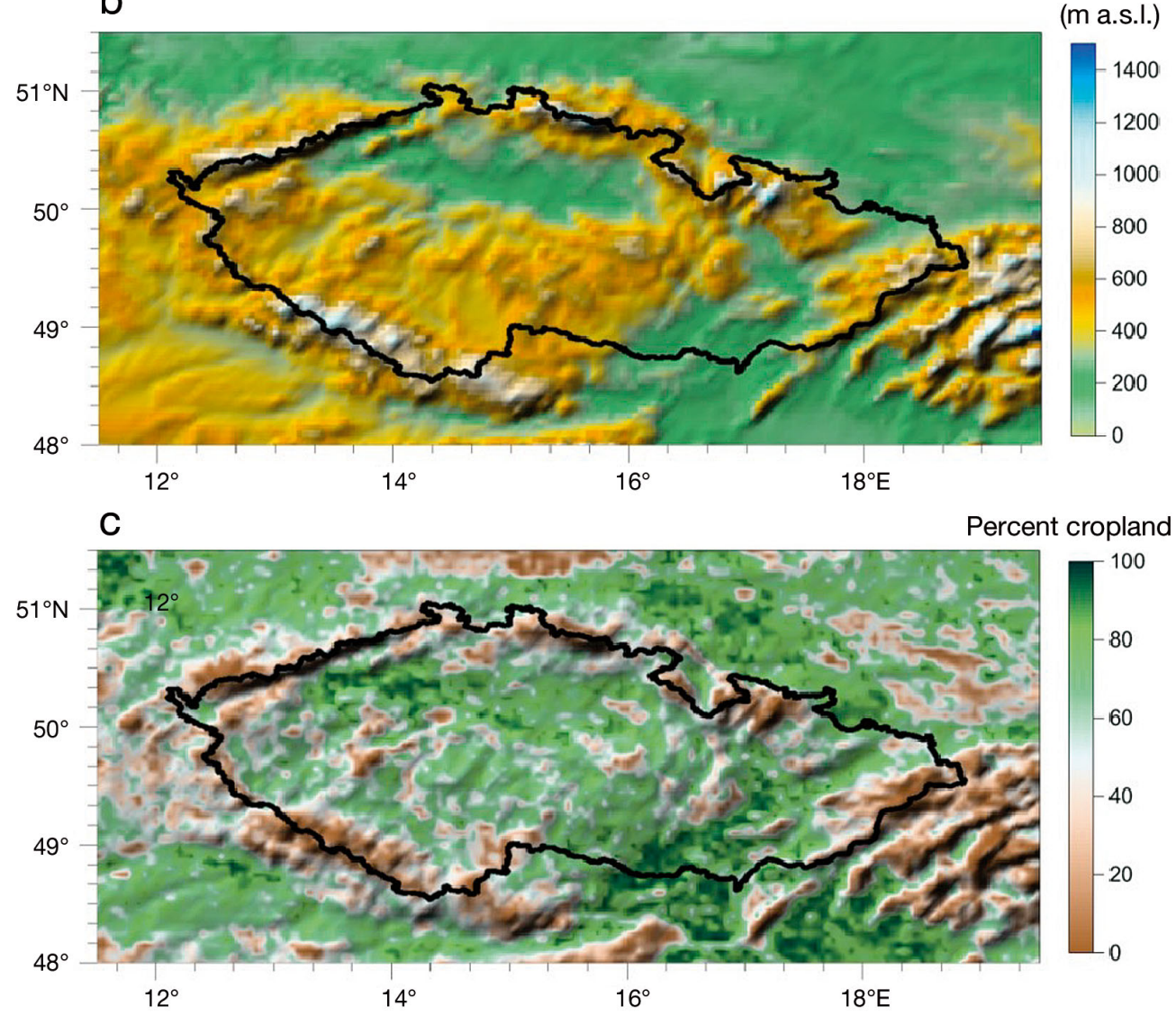

Fig. 1. Study area for investigation of relationships between the evaporative stress index (ESI) and crop yields in the Czech Republic (CR): (a) districts and regions included in the analysis (see Table 1 for abbreviations); (b) average elevation (m a.s.l.); (c) percent cropland in each $0.05^{\circ}$ grid cell

Moravia (OLK), and a region straddling the BohemianMoravian highlands (VYS).

In the $\mathrm{CR}$, the intensity of cropped area is highest at the lower elevations (JHM, STC and OLK) due to more favorable climate and water availability (Fig. 1b,c). While most crops in the CR are rainfed, irrigation is used to a limited extent as a supplemental water source, mostly for high value crops at the lowest elevations, e.g. in the river valleys in JHM and STC. In the highland regions, rainfall is more plentiful due to terrain-enhanced precipitation. JHC includes forested mountainous terrain bordering Germany, and has the lowest average cropping intensity of the regions studied.

\subsection{Yield data and crop characteristics}

This study focuses on 2 major cereal crops grown in the Czech Republic: winter wheat (Triticum aestivum L.) and spring barley (Hordeum vulgare). Together, they represented in $2015>42 \%$ of arable land $(31 \%$ 
Table 1. Abbreviations and summary data for districts and regions in the Czech Republic considered for study of relationships between the evaporative stress index (ESI) and wheat and barley yields. Average (Avg) percentages of cropland are based on Moderate Resolution Imaging Spectroradiometer (MODIS) data; crop yields show values for winter wheat and barley for the period 2002-2014

\begin{tabular}{|c|c|c|c|c|c|c|}
\hline $\begin{array}{l}\text { Abbre- } \\
\text { viation }\end{array}$ & District & Region & $\begin{array}{l}\text { Elevation } \\
\text { (m a.s.l.) }\end{array}$ & $\begin{array}{l}\text { Avg crop- } \\
\text { land (\%) }\end{array}$ & $\begin{array}{l}\text { Avg barley } \\
\text { yield }\left(\mathrm{t} \mathrm{ha}^{-1}\right)\end{array}$ & $\begin{array}{l}\text { Avg wheat } \\
\text { yield }\left(\mathrm{t} \mathrm{ha}^{-1}\right)\end{array}$ \\
\hline $\mathrm{BN}$ & Benešov & Středočeský kraj (STČ), & 430 & 66 & 3.9 & 5.4 \\
\hline $\mathrm{BE}$ & Beroun & Central Bohemia & 378 & 59 & 3.2 & 4.1 \\
\hline KD & Kladno & & 315 & 78 & 4.4 & 5.3 \\
\hline $\mathrm{KO}$ & Kolín & & 255 & 80 & 4.9 & 5.6 \\
\hline $\mathrm{KH}$ & Kutná Hora & & 361 & 71 & 4.8 & 5.9 \\
\hline MB & Mladá Boleslav & & 256 & 66 & 5.2 & 5.8 \\
\hline NB & Nymburk & & 195 & 75 & 5.0 & 5.7 \\
\hline PY & Praha-východ & & 302 & 70 & 5.1 & 5.9 \\
\hline PB & Příbram & & 483 & 50 & 3.9 & 4.9 \\
\hline RA & Rakovník & & 409 & 60 & 4.0 & 5.0 \\
\hline $\mathrm{JH}$ & Jindřichův Hradec & Jihočeský kraj (JHČ), & 509 & 47 & 4.1 & 4.9 \\
\hline PI & Písek & South Bohemia & 447 & 57 & 3.9 & 4.9 \\
\hline $\mathrm{ST}$ & Strakonice & & 477 & 66 & 3.8 & 5.0 \\
\hline HK & Hradec Králové & Královéhradecký & 243 & 74 & 5.5 & 6.5 \\
\hline $\mathrm{JC}$ & Jičín & kraj (HKK), & 308 & 68 & 5.2 & 6.2 \\
\hline NA & Náchod & Northeast Bohemia & 422 & 62 & 4.4 & 5.7 \\
\hline RK & Rychnov nad Kněžnou & & 465 & 53 & 4.4 & 5.2 \\
\hline TU & Trutnov & & 582 & 42 & 3.9 & 5.1 \\
\hline BK & Blansko & Jihomoravský kraj & 485 & 52 & 4.3 & 5.1 \\
\hline BI & Brno-venkov & (JHM), South Moravia & 325 & 68 & 4.5 & 5.2 \\
\hline BV & Břeclav & & 195 & 80 & 3.9 & 4.6 \\
\hline $\mathrm{HO}$ & Hodonín & & 252 & 68 & 4.2 & 4.9 \\
\hline VY & Vyškov & & 342 & 67 & 5.2 & 5.8 \\
\hline ZN & Znojmo & & 301 & 81 & 4.2 & 5.0 \\
\hline $\mathrm{OC}$ & Olomouc & Olomoucký kraj (OLK), & 406 & 62 & 5.5 & 6.5 \\
\hline PV & Prostějov & Northwest/Central & 374 & 77 & 5.5 & 6.5 \\
\hline PR & Přerov & Moravia & 307 & 77 & 4.8 & 5.7 \\
\hline $\mathrm{HB}$ & Havlíčkův Brod & Kraj Vysočina (VYS), & 494 & 67 & 4.5 & 5.3 \\
\hline JI & Jihlava & Bohemian-Moravian & 579 & 63 & 4.8 & 5.8 \\
\hline PE & Pelhřimov & Highlands & 570 & 65 & 4.4 & 5.3 \\
\hline TR & Třebíč & & 473 & 75 & 4.1 & 5.3 \\
\hline ZR & Ždár nad Sázavou & & 577 & 61 & 4.7 & 5.5 \\
\hline
\end{tabular}

for winter wheat and $11 \%$ for spring barley) according the Czech Statistical Office (https://vdb.czso.cz/ vdbvo2/faces/en/index.jsf). The percentage of total acreage comprised of spring barley was even higher in the early part of the analyzed period due to the higher demand for feed grain. Winter wheat is typically sown in late September and spring barley in late March. They are usually harvested from early July to mid August, depending on the season.

These crops were chosen in part to investigate differences in ESI sensitivity for winter versus spring crops. Winter crops are typically less sensitive to spring and summer droughts because they already have well-established rooting systems as the warm growing season commences (Hlavinka et al. 2009). However, they are more sensitive to fall drought and lack of snow cover (Zahradníček et al. 2015). Establishing a parity between spring and winter cereal crops distributes climatic risk and may be an effective means for climatic adapation.
Yield data for the period 2002-2014 were obtained primarily from the Ministry of Agriculture of the Czech Republic (http://eagri.cz/public/web/en/mze/). In districts and years where it was difficult to find any existing data, yield estimates from the Czech Agrarian Chamber were used (www.agrocr.cz/?lang=2). The Czech Agrarian Chamber is an organization of entities doing business in agriculture, forestry and the food industry, and supporting business activities in these areas.

These yield estimates were developed from statistical surveys of farmers operating in each agricultural district, and may have some level of bias due to sampling structure. Differences in the composition and size of the farm sample might also be an issue in several districts. The yield estimates therefore have some level of uncertainty and tend to be lower than observations obtained from small experimental fields. Furthermore, yield estimates are based on area harvested rather than area planted. On years 
with very poor growing conditions, these estimates may underestimate true yield losses as abandoned crops are not accounted for. Still, they reasonably represent existing variability in the yield levels that can be explained by climatic factors and have been effectively used for spatial analyses of agricultural production in the CR (e.g. Hlavinka et al. 2009, Trnka et al. 2012).

\subsection{Evaporative stress index}

The ESI represents standardized anomalies in the ratio of actual-to-reference ET ( $\left.f_{R E T}\right)$, highlighting areas where landscape evaporative fluxes, including the crop transpiration rate in cropped areas, are higher or lower than normal for a given seasonal interval. Normalization by reference ET reduces the impact of climate and radiation drivers on the ET flux, making the ESI more specifically responsive to soil moisture drivers. A standard FAO-56 PenmanMonteith reference ET for grass (Allen et al. 1998) is used for normalization, based on sensitivity tests by Anderson et al. (2013).

This study uses ESI data for 2002-2014 extracted from a global product created at $0.05^{\circ}$ resolution (roughly $5 \mathrm{~km}$ ) and weekly timesteps. The actual ET data are generated with the time-differential Atmosphere-Land Exchange Inverse (ALEXI) surface energy balance model using day-night temperature differences from the Moderate Resolution Imaging Spectroradiometer (MODIS) on board the Aqua satellite (Anderson et al. 2015). The global ESI products are routinely created for 4, 8 and 12 wk (roughly 1, 2 and $3 \mathrm{mo}$ ) composite timeframes to represent different temporal scales of drought and pluvial conditions. These products are referred to as ESI-1, ESI-2 and ESI-3, respectively. Composited $\mathrm{f}_{\mathrm{RET}}$ values over these time frames are differenced with climatological mean values and normalized by the variability in $f_{\text {RET }}$ over the period of record. For more details, see Anderson et al. (2015).

\subsection{Regional variables}

\subsubsection{Elevation}

Elevation data (Fig. 1b) were obtained from the Global 30-Arc-Second Elevation dataset (GTOPO30; Gesch et al. 1999) and averaged onto the $0.05^{\circ} \mathrm{ESI}$ grid. Elevation is one factor used to understand variations in the ESI-yield relationships.

\subsubsection{Percent cropland}

Percent cropland in Fig. 1c was extracted from a global $1 \mathrm{~km}$ consensus land-cover product which is based on a harmonization of several individual products (Tuanmu \& Jetz 2014), including GlobCover (Bicheron et al. 2011), the MODIS land-cover product (MCD12Q1; Friedl et al. 2010), GLC2000 (Bartholomé \& Belward 2005) and DISCover-IGBP (Loveland \& Belward 1997). The product was aggregated to the $0.05^{\circ} \mathrm{ESI}$ grid.

\subsubsection{Climatological variables}

District level measures of average air temperature and precipitation for April to September were obtained from Hlavinka et al. (2009). These variables were determined from station data collected over the period 1961-2000. Although these data do not overlap the period of record studied here, we make the assumption that the relative inter-district variability in climatological variables has not changed significantly, although the absolute values are not likely to be stationary.

\subsection{Yield correlations}

To better constrain the analysis to agricultural zones within each district, ESI data were averaged over each district area using only pixels with percent cropland $>50 \%$ as defined by the MODIS product described in Section 2.4.2. This threshold was selected to minimize contributions from pixels with predominantly forest, urban or natural vegetation cover while still retaining a reasonable sample size for district averaging. Anderson et al. (2015) demonstrated that the ESI behavior of forested areas in Brazil in the face of drought significantly differed from that of agriculture and short vegetation. This may be due to a combination of physiological effects or deeper rooting depths characteristic of forests, which add resilience to moisture deficit events. Masking contributions from forest and other nonagricultural landcovers improved ESI-yield correlations in the current study.

Yield anomalies were computed at the district level as departures from a linear regression in time over the 2002-2014 period to remove trends in increasing annual yield that may result from technological advances, land management changes or genetic improvements in cultivars, as follows:

$$
\text { yield }(u, y)^{\prime}=\operatorname{yield}(u, y)-y_{\text {ield }}(u, y)
$$


where $u$ is the political unit in question (CR district), $y$ is the year, and yield $d_{\text {lin }}$ is given by a linear temporal fit to all yield data for that unit over the period of record.

ESI-yield correlations were quantified using the Pearson correlation coefficient (r) computed from $n y$ $\times n s$ samples, where $n y=13$ is the number of years of yield data included in the analysis (2002-2014), and $n s$ is the number of districts included in a regional evaluation, which varies from region to region.

For district-level yield analyses, correlations were computed at $7 \mathrm{~d}$ intervals between ESI-3 and yield anomalies (Eq. 1). In order to identify optimal compositing windows during the growing season when an index is most predictive of at-harvest yield, a 2-dimensional correlation space was computed for each index, crop and region. In these analytical plots, the $x$-axis represents the end-date of the index averaging window, and the $y$-axis represents the length of the window.

\section{RESULTS AND DISCUSSION}

\subsection{Regional timeseries}

Annual maps of ESI-3 (3 mo composites) and detrended yield anomalies for winter wheat and spring barley crops in the targeted districts for 20022014 are shown in Fig. 2. ESI maps for Week 26 (3 mo period ending 2 July) and Week 30 (ending 29 July) are included to represent the periods of peak correlation with winter wheat and spring barley yield anomalies, respectively (see Section 3.2). In general, there is reasonable spatial and temporal correspondence between the 2 datasets. Drought years (2003, 2006, 2007 and 2012) with large yield reductions were captured by negative anomalies in the ESI. In addition, the high-yield years of 2004 and 2014 are associated with positive ESI values (green in Fig. 2). JHM shows particularly strong interannual volatility in yields (e.g. contrast 2011, 2012 and 2013), related to highly variable rainfall amounts. The 2012 drought in some south Moravian districts was classified as the worst in 130 years, with subtantial yield reductions (particularly in winter crops) and even wildfire outbreaks, which are fairly rare in the region (Zahradníček et al. 2015). In 2009 and 2010, differences in ESI-3 maps between Weeks 26 and 30 indicate rapidly changing moisture conditions during the summer season, in both cases associated with average or below-average yields.

In Fig. 3, time series of district-averaged ESI and yield data for representative districts in each region provide an example of inputs to the temporal correlation analyses discussed in the following sections.
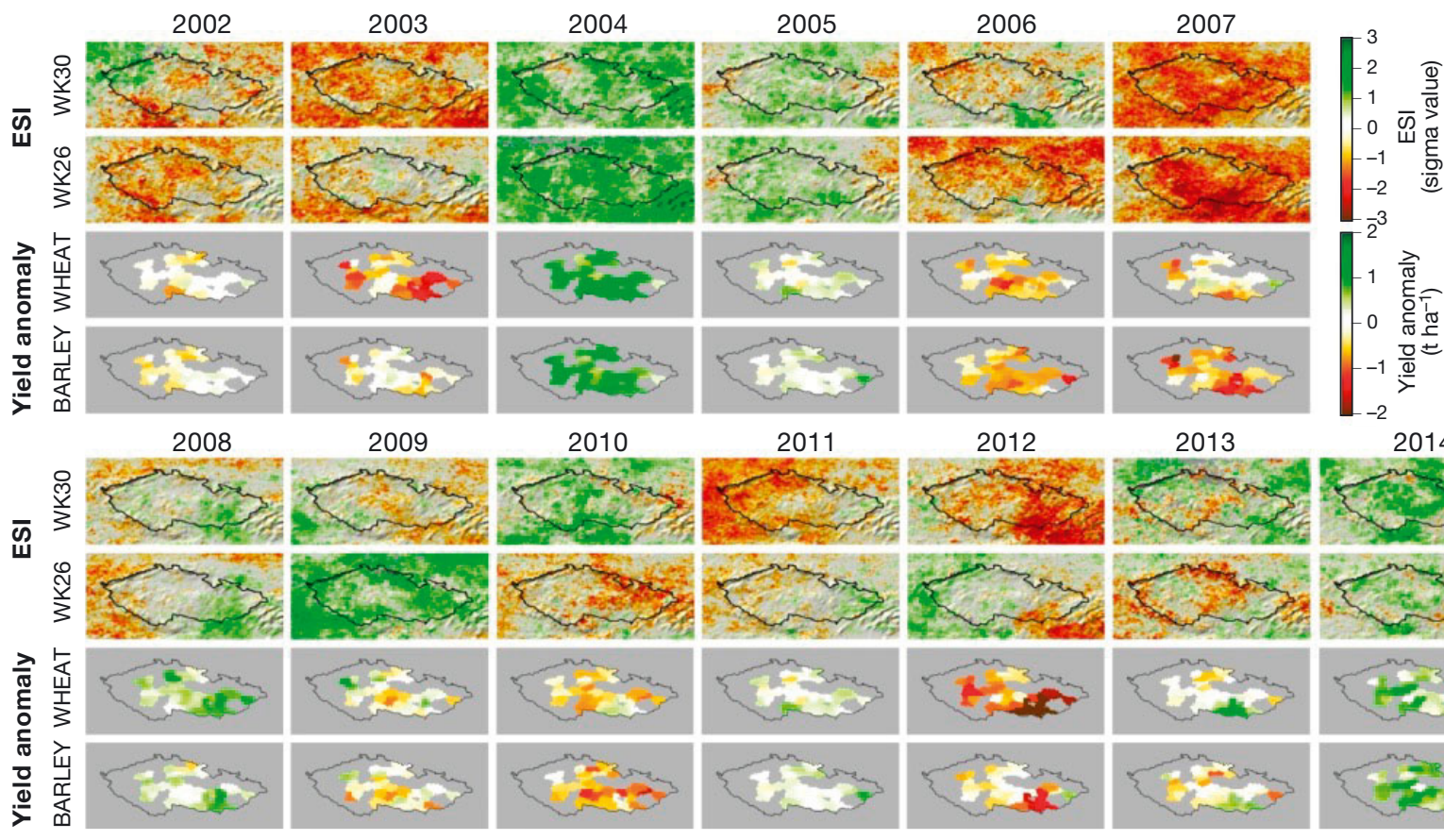

2012
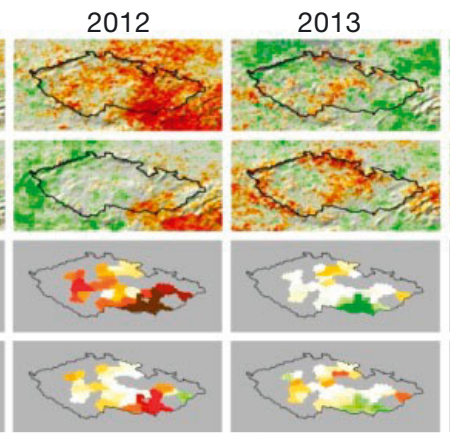

Fig. 2. Time series of maps for 2002-2014 of the 3 mo composite evaporative stress index (ESI-3; in units of sigma values) for Weeks 26 and 30 compared to yield anomalies $\left(\mathrm{t} \mathrm{ha}^{-1}\right)$ for winter wheat and spring barley crops in target agricultural districts in the Czech Republic 
These plots clearly demonstrate widespread yield reductions in both 2003 and 2012, particularly in Moravia (JHM and OLK), corresponding to mid-year negative spikes in ESI. However, as in the case of 2007 or most recently 2015, even quite pronounced spring or summer drought may not necessarily lead to severe yield reduction. In these years, the impacts were mitigated, particularly for winter crops, by an earlier start of season which caused the crops to overwinter better and in general establish deeper and more resilient root systems (Trnka et al. 2015). In contrast, droughts that occur in late fall the prior year will be more detrimental to winter crop yields (e.g. in 2012).
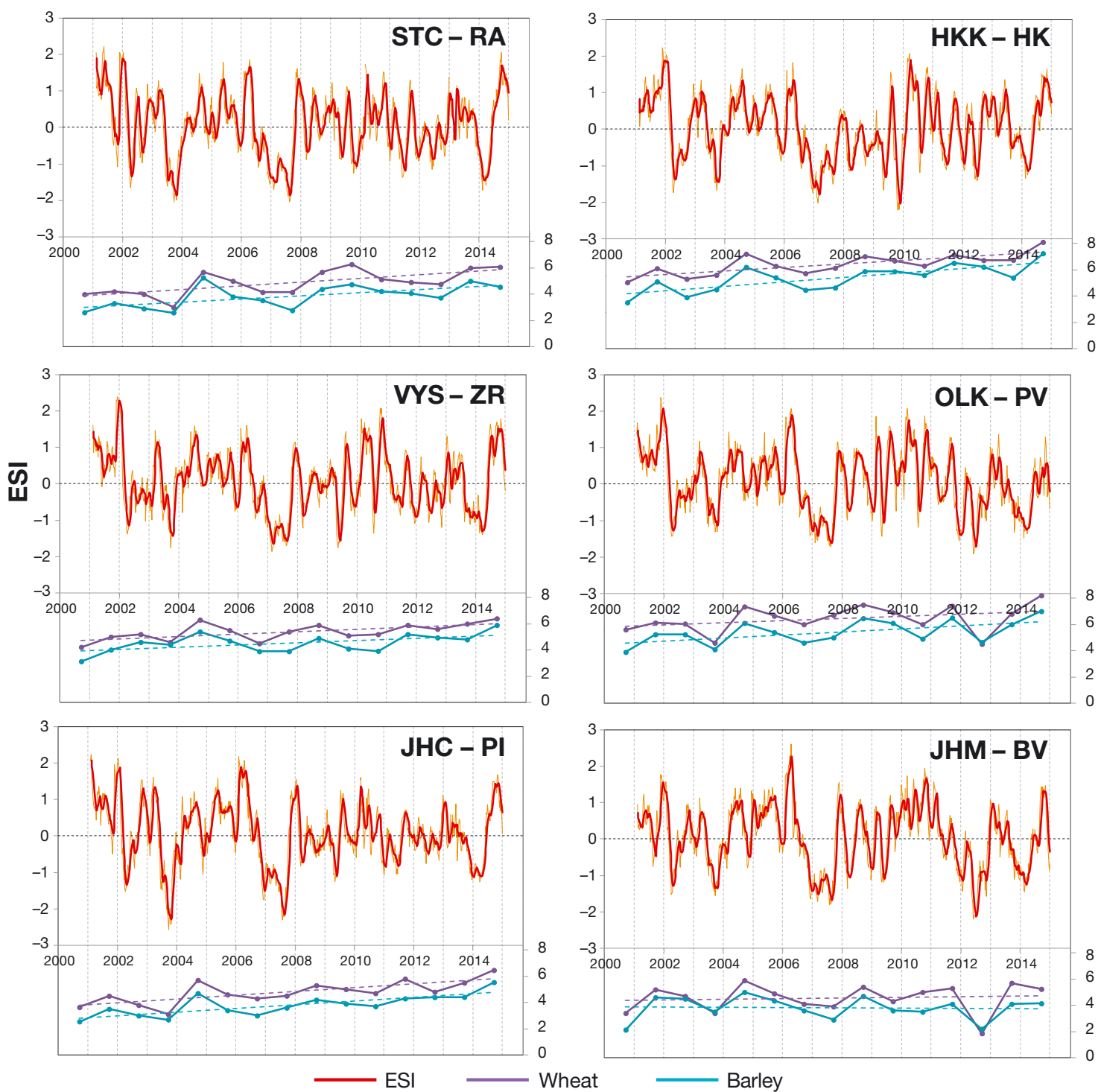

Fig. 3. ESI-3 timeseries averaged over representative districts for each region (see Table 1 for abbrviations) included in the analysis (thin orange line), compared with annual winter wheat (purple line) and spring barley (blue line) yields and linear yield trends (dashed lines). A 6 wk moving average of ESI-3 (thick red line) is included to highlight longer timescale signals 
diverse for winter wheat than for spring barley, which is typically above 0.6 (excluding JHC). Due to the longer growing season, winter wheat crops are susceptible to a wider range of climatic events than is spring barley, including fall and summer droughts as well as winter snow cover duration and frosts (Kolár et al. 2014). In some districts, this will reduce indexyield correlations or diffuse them over a broader range in time. Correlations tend to peak earlier for winter wheat, during the 3 mo period ending around Weeks 26 to 28 (early to mid July), with earlier and higher peaks in Moravia than in the Bohemian regions. Spring barley peak correlations occur between Weeks 28 to 30 (mid to late July). Using ESI-1, the peaks correlations occur about 2 wk earlier, although the results have higher noise levels (not shown; the utility of shorter compositing intervals for crop modeling is discussed further in Section 3.4). In general, these findings are consistent with the nominal April-June periods of peak moisture sensitivity identified for these crops by Hlavinka et al. (2009) using a modified Palmer drought severity index, encompassing the critical yield-determining phenophases of grain development for both crops.

For both crops, JHC is an outlier, with statistically insignificant ESI-yield anomaly correlations $(<0.4)$ throughout the growing season suggesting that moisture limitations on crop growth are not strong. This may be due in part to the higher preciptation rates and relatively shallow groundwater tables character- istic of this region. Also the proportion of agricultural land used for growing wheat and barley in JHC is small compared to the other regions studies, with large areas of the region's cropped land used for grazing or fodder production. In contrast, JHM shows the highest peak correlations, between 0.7 and 0.8. Large year-to-year variations in yield experienced in this region (noted in Section 3.1) contribute to the higher magnitudes of correlation here. The regional curves in Fig. 4 for CR crops demonstrate a significantly higher degree of inter-coherence in comparison with results obtained for state-level yields over Brazil (Anderson et al. 2016), likely due to the much smaller geographic extent of the study area in the current analysis.

Correlation window maps in Fig. 5 (described in Section 2.5) expand on the information in Fig. 4, showing correlations obtained over a broad range of index averaging windows. The maps represent correlations obtained for all districts combined, and segregated by region. These plots demonstrate the consistency in peak correlation timing between regions (i.e. the location of green maxima along the $x$-axis), as well as the relative strength of correlation between ESI and crop yields. OLK shows a tendency toward anticorrelation with ESI conditions $(\mathrm{r} \sim-0.4)$ around Week 10 for both crops. While this is likely an artifact of the specific set of moisture patterns that occured during the period of record, it does highlight the rapid high-amplitude within-season variability in ESI characteristic of this region (see Fig. 3). JHC, on
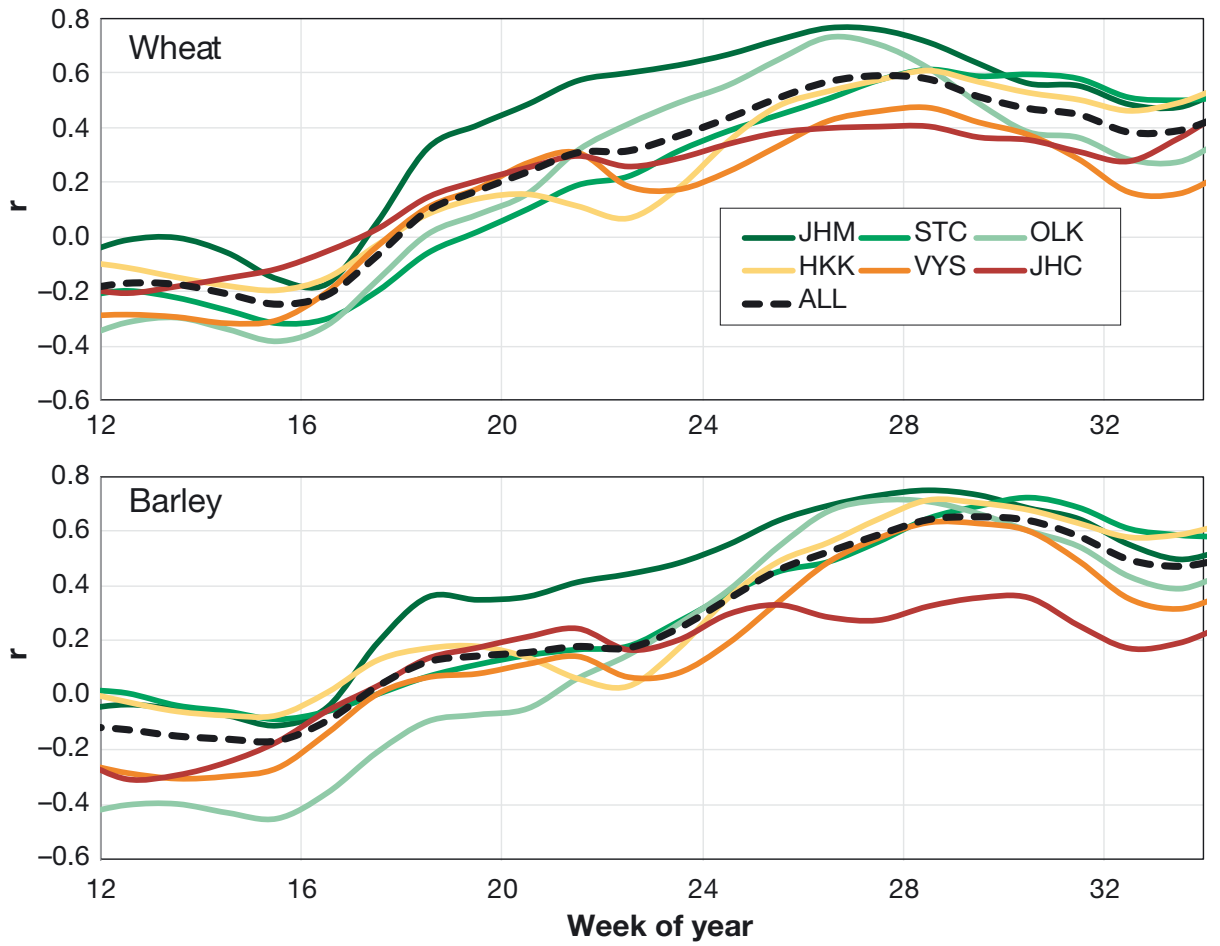

Fig. 4. Correlations between ESI-3 and (a) wheat and (b) barley yield anomalies for 2002-2014 in the Czech Republic as a function of end date (week of year) of the 3 mo composite index value, shown for each region and for all districts combined (ALL). See Table 1 for abbreviations of regions 
the other hand, shows signals of even stronger anticorrelation with moisture conditions in the year prior to the current growing season. This too appears to be an artifact, driven largely by strong yield anomalies of opposite magnitude in 2003 and 2004 (Fig. 3). Such artificial features should diminish as more years of yield and remote sensing data become available.

Based on Fig. 5, the ranking in peak correlation strength by region is similar between crops, with JHM and OLK (Moravia) having the highest correlations, followed by HKK and STC (Bohemia), with JHC and VYS (southern highlands) consistently having the lowest correlations. Fig. 6 details correlation window maps for districts within JHM, demonstrating a consistency in correlation structures typical within most of the regions analyzed. Yield departures in the BV district for both crops are strongly related

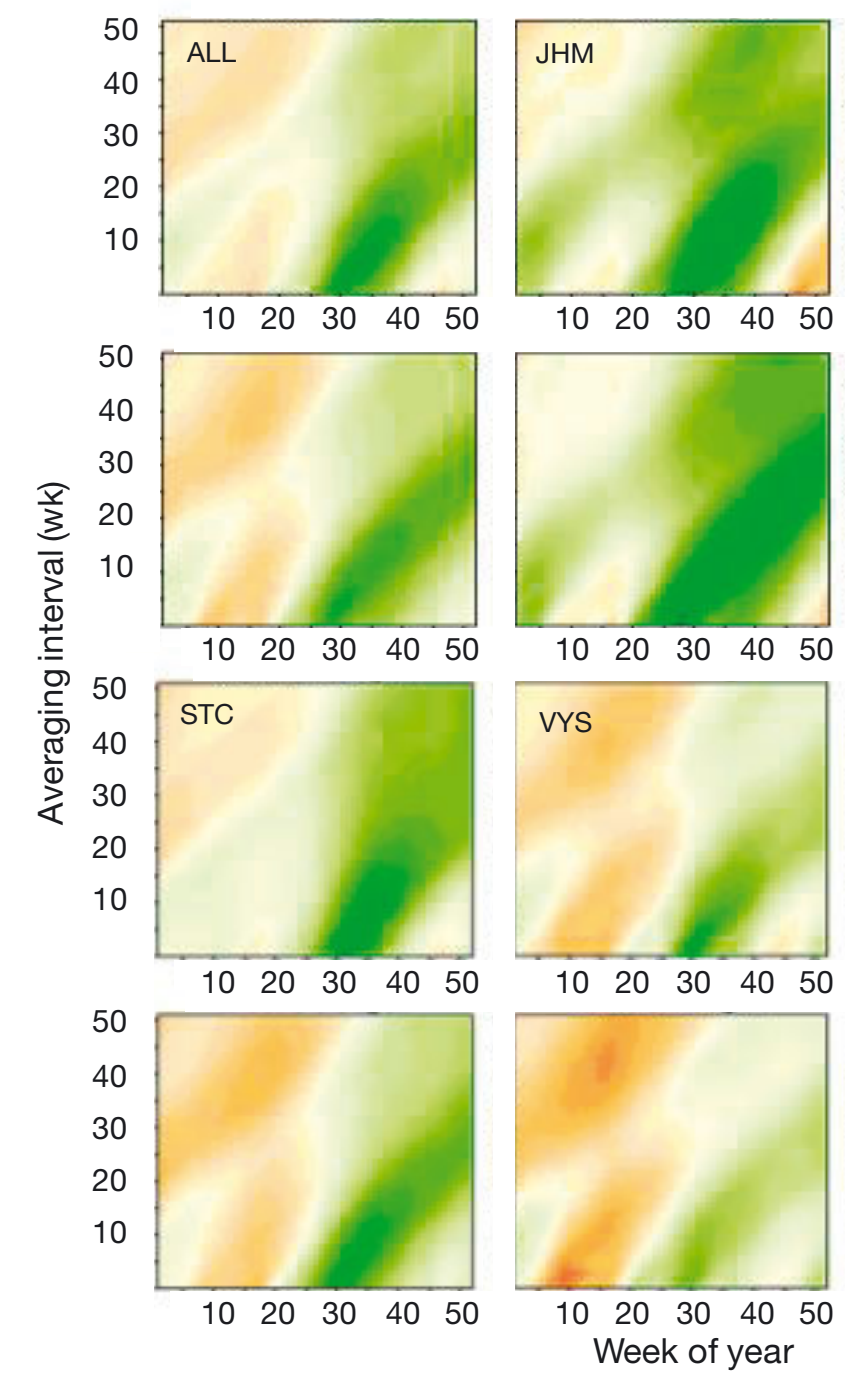

to ESI variations, with peak correlations of 0.85 for winter wheat and 0.81 for spring barley occurring around Weeks 26 to 27 . BV is located in a valley at the confluence of the Dyje and Morava rivers, and is the climatologically warmest and driest of all the districts studied, accounting for the high susceptibility of crops to the moisture limiting conditions expressed in the ESI. Potential drivers of regional and interdistrict variations in correlation strength are further considered in the following section.

\subsection{Regional maps of correlation properties}

Fig. 7 contains maps of various quantities describing the spatial variation in correlation between ESI and yield anomalies (timing and magnitude of peak
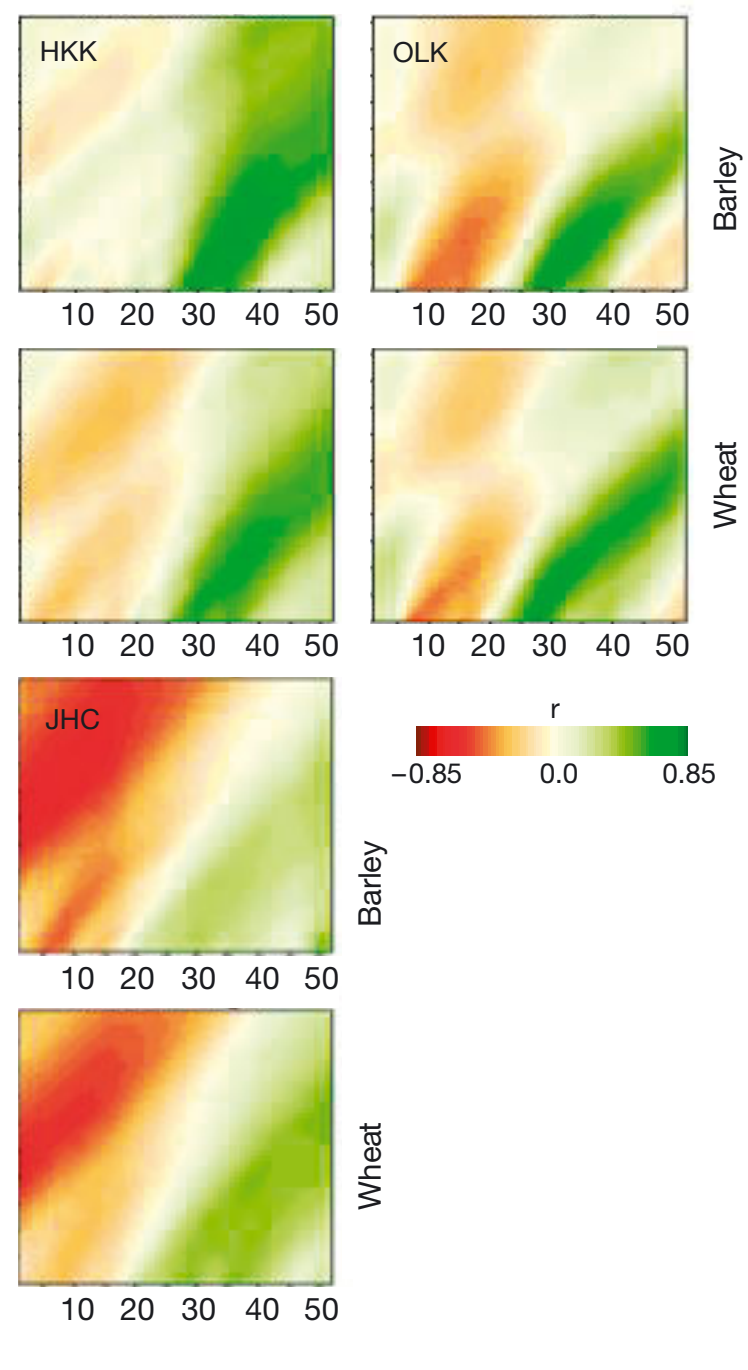

Fig. 5. Correlation of wheat and barley yield anomalies with ESI, plotted as a function of index averaging interval and end date for all 32 districts combined (ALL), and for each individual region. See Table 1 for abbreviations of regions 
correlation, and regression yield errors) and potential drivers thereof (yield variability, cropping intensity, elevation, climate). Here 'yield error' is defined as the root mean square difference of the observed yield departures around the ESI-yield regression developed for the week with peak correlation. While it is not a true expected error in predicted yield since it has not been established using an independent data sample, it does provide some estimate of the expected spatial variability in predicted yield accuracy based on the quality of the regression. As more years of yield data become available, independent testing will become more feasible. Relative yield error is computed as yield error divided by the average yield observed over the 13 yr period of record.

In particular, we examine the role of elevation, climate, and yield stability, as described by the coeffi- cient of variation (CV) in observed yield over time, as potential factors that might influence the correlation between ESI and yield anomalies in the CR. At higher elevations, the likelihood is increased that energy limitations (i.e. temperature and insolation) dominate over moisture constraints represented in the ESI. In areas with low yield variability, due to reliable growing conditions or irrigation or other factors that may stabilize yield from year to year, lower correlation coefficients may be expected with any crop indicator due to limitations in the range of variation (LópezLozano et al. 2015, Anderson et al. 2016).

As seen in Fig. 7 and in the scatter plots in Fig. 8, each of these factors appears to be spatially related to ESI correlation strength. The lowest ESI correlations are uniformly obtained at the highest elevations. This relationship reflects the effects of elevation-dependent

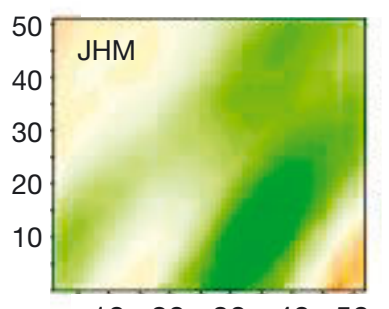

$\begin{array}{lllll}10 & 20 & 30 & 40 & 50\end{array}$
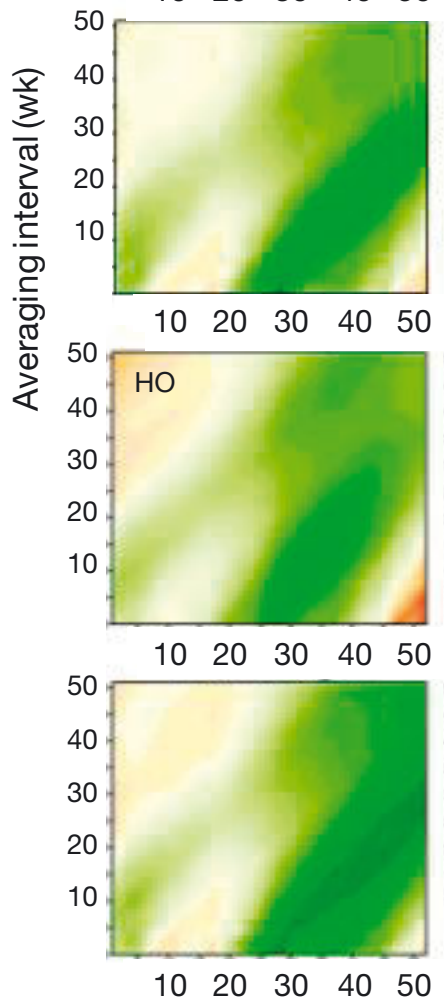

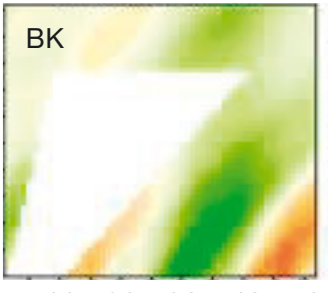

$10 \quad 20 \quad 30 \quad 40 \quad 50$
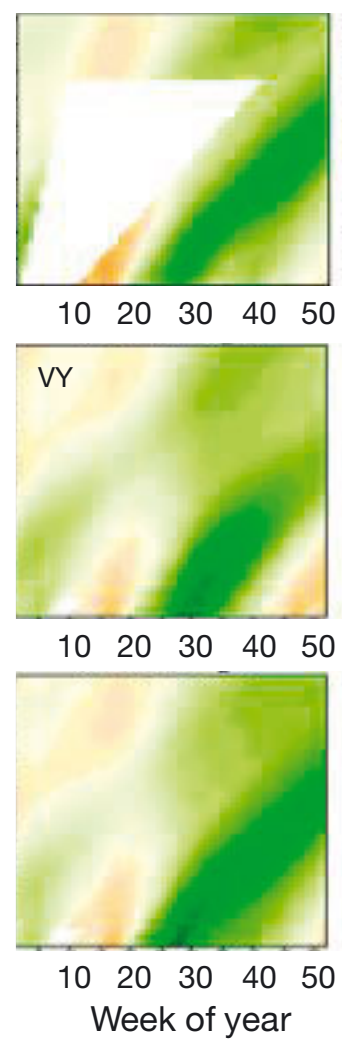

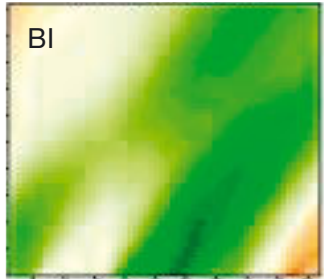

$10 \quad 20 \quad 30 \quad 40 \quad 50$
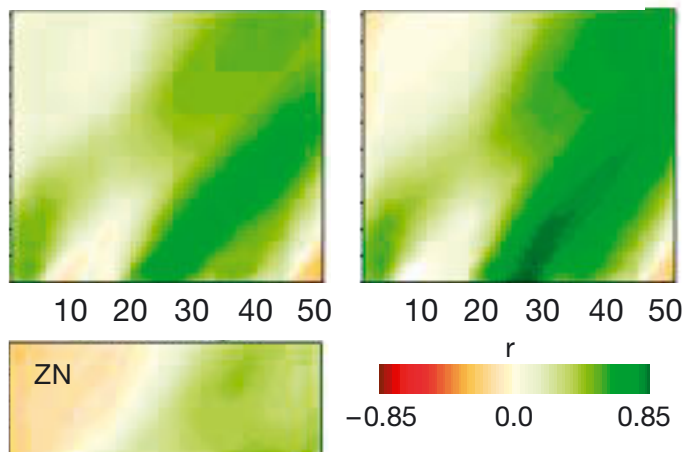

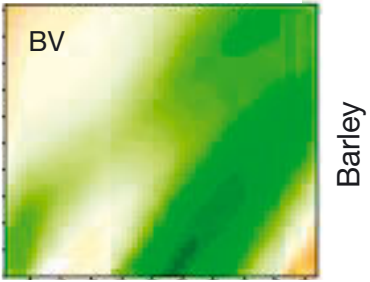

$10 \quad 20 \quad 30 \quad 40 \quad 50$
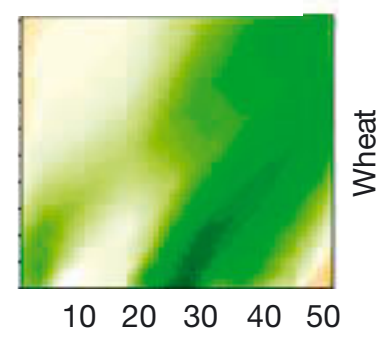

\section{$\frac{\widehat{D}}{\infty}$}
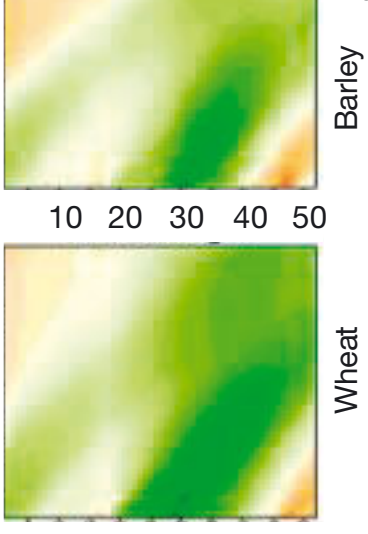

$10 \quad 20 \quad 30 \quad 40 \quad 50$

Fig. 6. Correlation of wheat and barley yield anomalies with ESI, plotted as a function of index averaging interval and end date for districts within the JHM (south Moravia) region. See Table 1 for abbreviations of districts 
precipitation and temperature regimes, with higher correlations under the drier and warmer climates typically found at lower elevations in the CR, characterizing moisture-limiting growth conditions as in JHM (Fig. 7). These low elevation areas also tend to have higher interannual yield variability. Similar
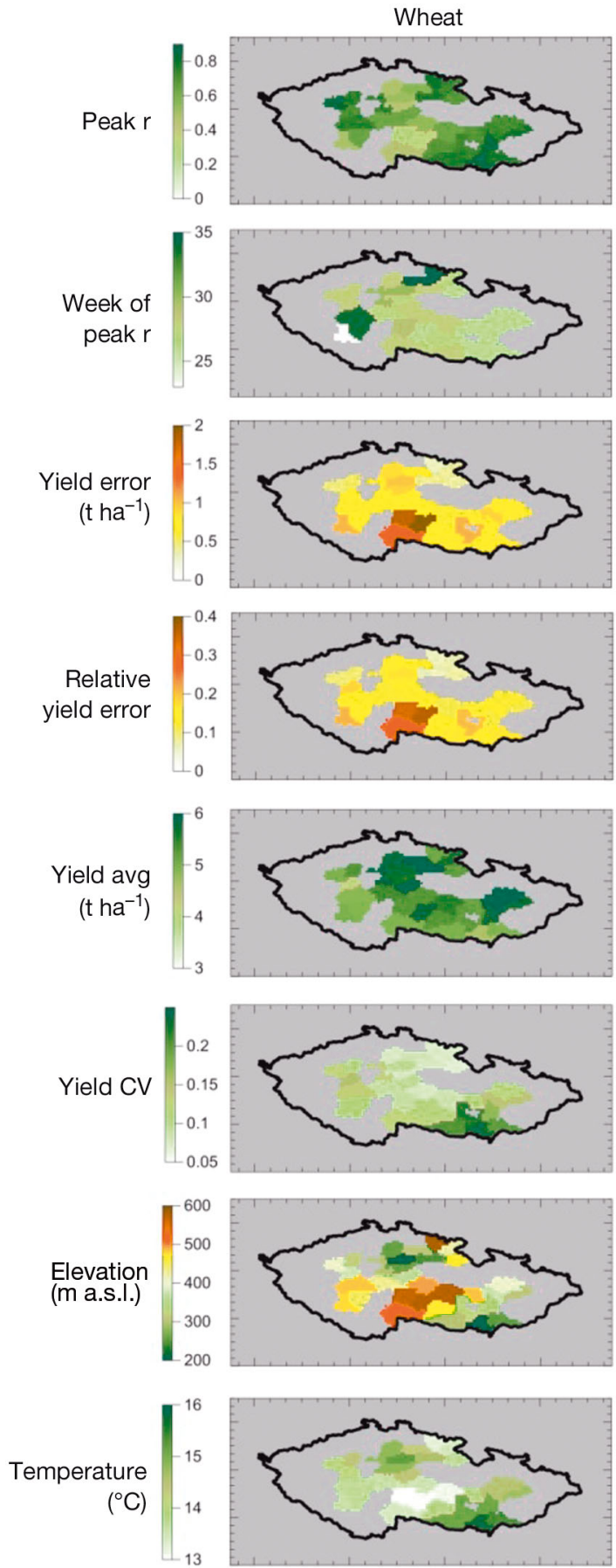

relationships were evident in agricultural regions in Brazil, where highest ESI performance was observed in the semiarid northeast regions, as well as the more humid south which experienced several episodes of flash drought during the study period (Anderson et al. 2016). In the higher elevation districts where rain-
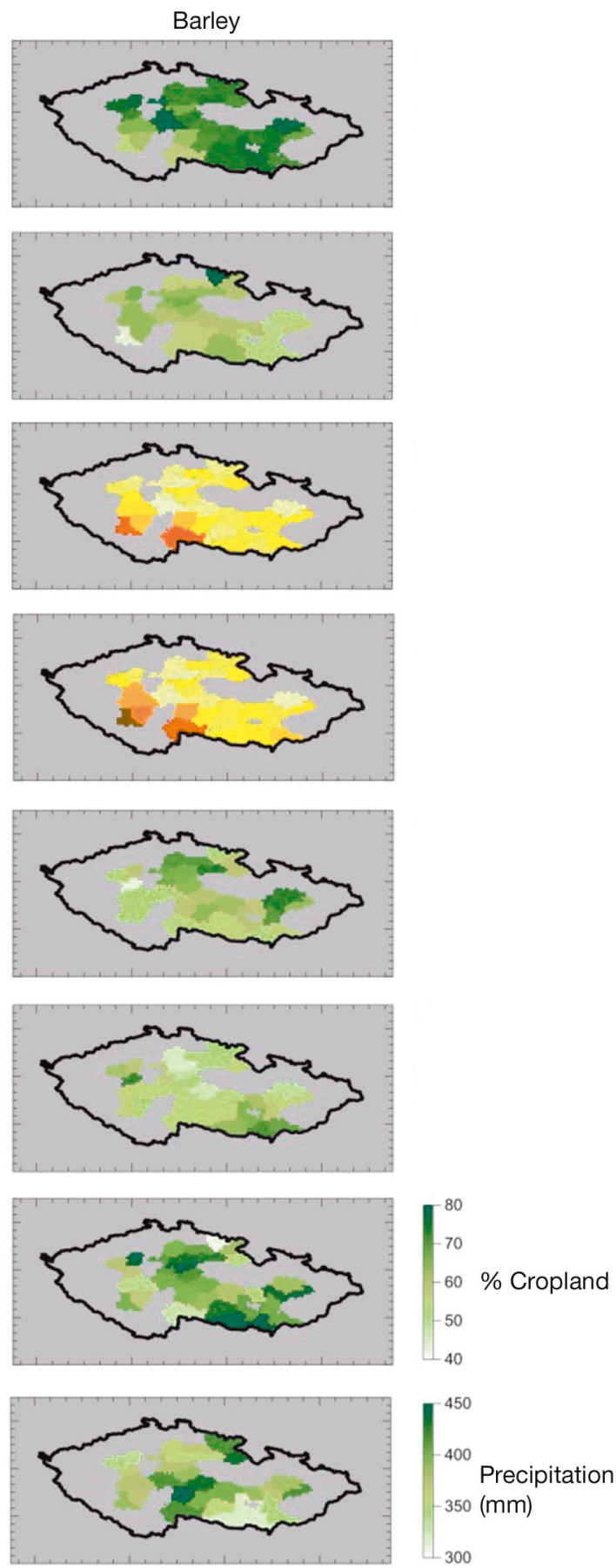

Fig. 7. Maps of properties describing ESI-yield anomaly correlation strength (r-values) for wheat and barley and potential factors that may influence correlations, including yield coefficient of variation (CV), elevation, percentage of cropland, and climatological temperature and precipitation rates 

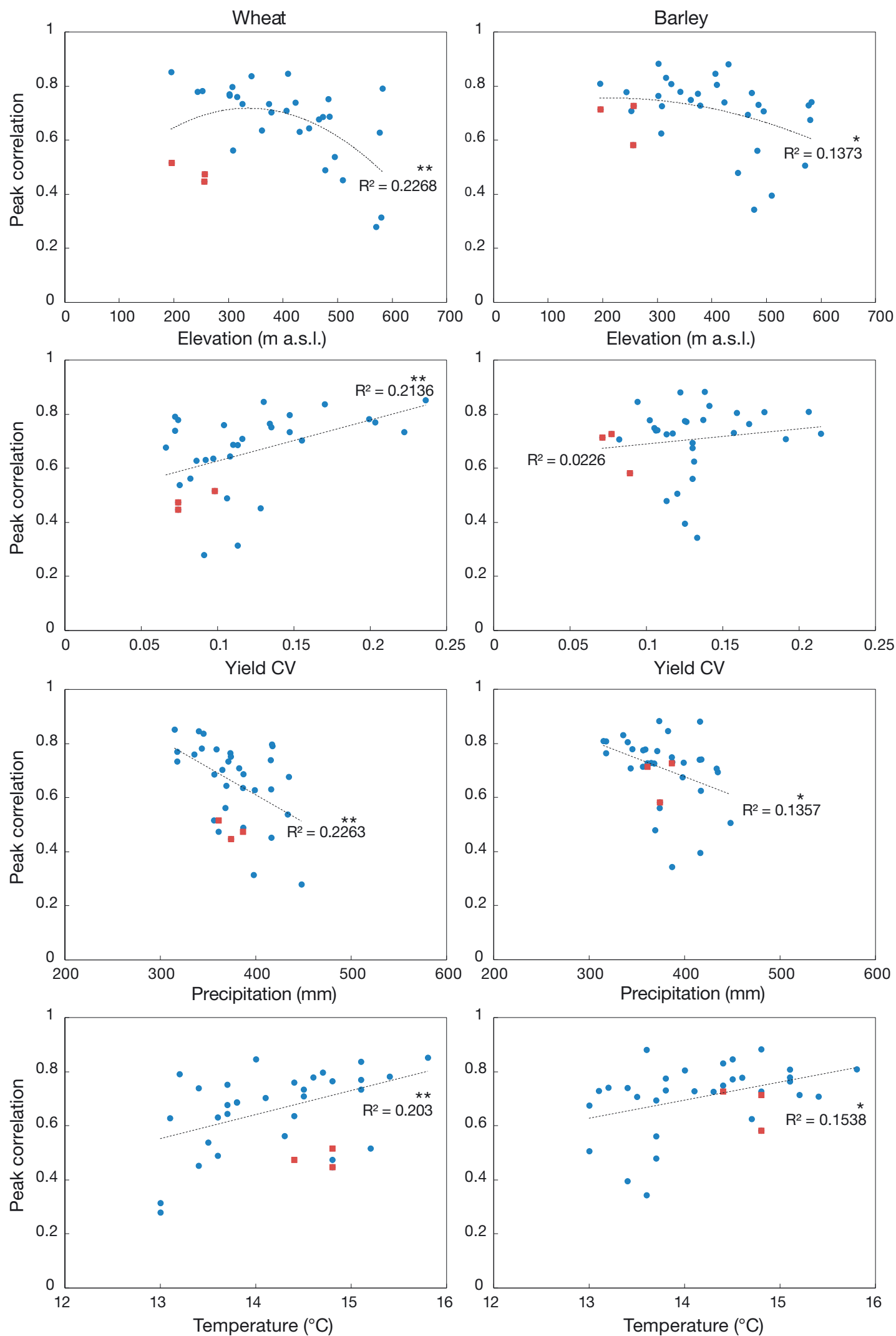

Fig. 8. Comparison of peak ESI-yield anomaly correlation with elevation, yield CV, precipitation and temperature for each target district. Red markers indicate districts KO, MB and NV near the Labe River in STC (see Table 1 for abbreviations of regions and districts). Asterisks indicate correlation with linear or second order polynomial fit is signicant at ${ }^{*} \mathrm{p}<0.05$ and ${ }^{* *} \mathrm{p}<0.01$ 
fall is typically adequate and growing degree days may be a more relevant constraint, it may be that anomalies in LST itself might outperform ESI in terms of yield correlation.

Anomalous districts ( $\mathrm{KO}, \mathrm{MB}$ and $\mathrm{NV}$; shown by red markers in Fig. 8) with relatively low ESI-yield correlations at low elevations, particularly for wheat, are located close to the Labe River (in Germany, known as the Elbe River) in the STC region. These districts also have unusually low yield CV amongst the low-elevation districts (along with HK, also near the Labe River). The lower ESI performance in STC compared to JHM may be related to somewhat higher regional rainfall rates. Furthermore, the $0.05^{\circ}$ ESI signal in this area may be capturing additional moisture signals from shallow groundwater and riparian vegetation along the Labe, or from irrigated fields, which while not extensive, are most concentrated in this region. Hain et al. (2015) discuss impacts of ancillary land-surface moisture sources on ET estimates retrieved with ALEXI. This may point to the benefit of using higher resolution ESI products for the CR, to better mask non-agricultural sub-pixel contributions to the perceived crop stress signal.

Relative yield error in the optimal regression function for both winter wheat and spring barley is relatively uniform across regions with the exception of districts in JHC and VYS, where $\mathrm{JH}, \mathrm{ST}$, JI and PE have average errors $>20 \%$ (Fig. 7). Errors in yield departures around the ESI regression function for the week of peak correlation are $\sim 13 \%$ for both crops in districts at elevations $<450 \mathrm{~m}$, with the highest errors in districts $>500 \mathrm{~m}$ (Fig. 9). Future investigations will quantify actual prediction errors for each yieldreporting district within the $\mathrm{CR}$.

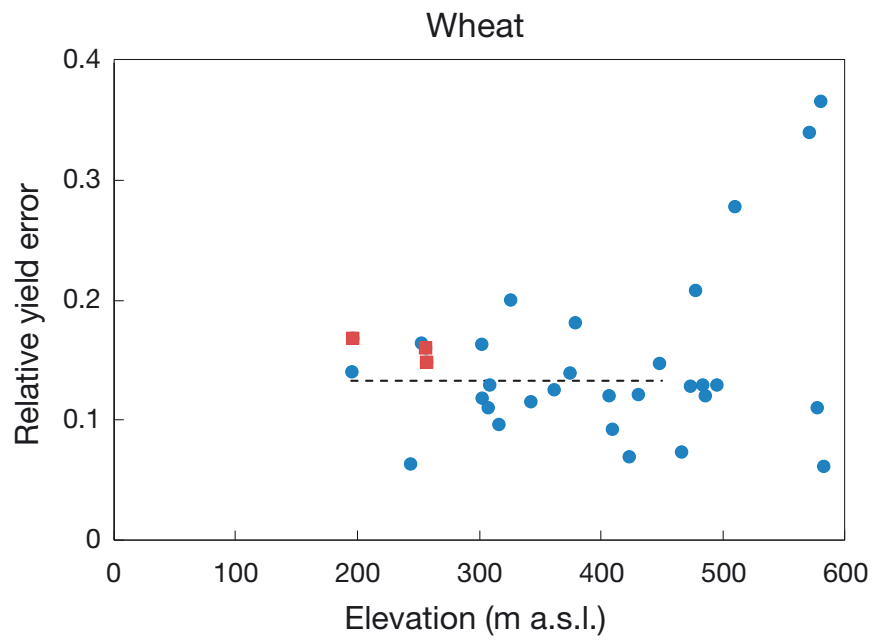

\subsection{Spatiotemporal considerations for an operational yield forecasting system}

In this study, a 3 mo ESI composite was used to suppress temporal noise in the correlation curves and to better highlight regional variability in the relationship between ET and yield anomalies. This window, however, is too broad to capture in detail stress events occuring during specific critical phenological stages, such as flowering, when crop yield development is most sensitive to soil moisture deficits. Similarly, the $5 \mathrm{~km}$ resolution of the ESI product used here does not allow for the discernment of differences in phenological development between individual crop types. Delayed emergence of a subset of crops within a $5 \mathrm{~km}$ pixel, due for example to unusually wet or cold conditions around the planting date, can result in a negative ET anomaly during green-up, which may be falsely interpreted as a drought signal (Anderson et al. 2013).

Yield correlation analyses, such as those presented here, can be considered a first step in elucidating the relative value of remotely sensed indices as predictors of yield anomalies, as well as general spatial and temporal patterns of index performance. With this understanding, the indicators can be more effectively combined within the context of a physiologically based crop modeling framework that takes into consideration stress timing relative to phenological stage in predicting yield impacts. For yield forecasting applications, the moisture stress datastreams will be most usefully developed at spatial resolutions where a significant number of pure crop pixels can be extracted over the region of interest, and at the highest temporal resolution afforded by the remote sensing methods employed.

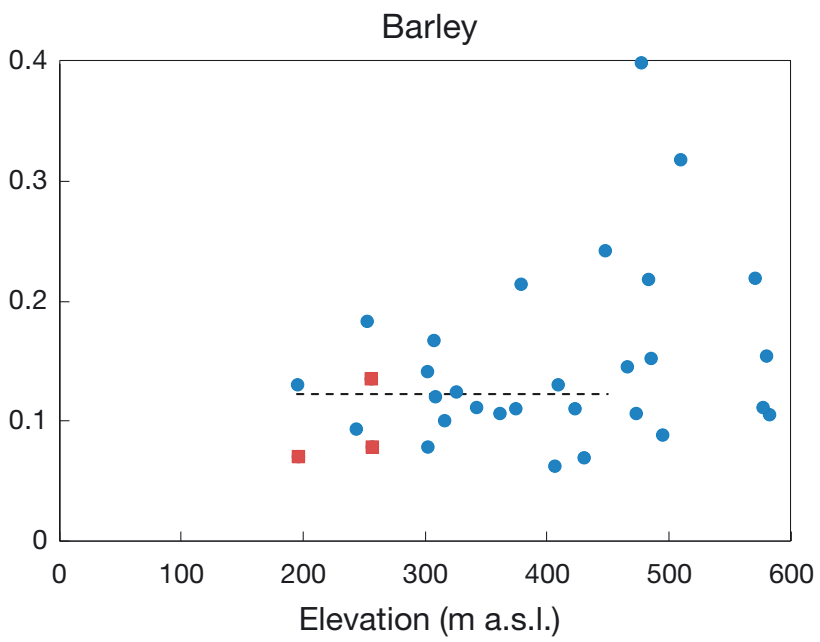

Fig. 9. Relative yield error versus average district elevation for winter wheat and spring barley crops. Dotted line indicates average error for districts below $450 \mathrm{~m}$. Red markers indicate districts KO, MB and NV (see Table 1 for abbreviations) 
The average field size in the CR is relatively large in comparison with neighboring countries in the European Union due to the period of collectivization that occurred after World War II, making this region conducive for agricultural remote sensing studies. The 2010 Agricultural Census for the CR (www.czso. cz/csu/czso/2127-12-eng_n_2012-2) gives an estimated mean field block size (i.e. the part of the field with the same crop in a given season) as being over 20 ha $\left(\sim 450 \times 450 \mathrm{~m}^{2}\right)$, which is 2 orders of magnitude larger than in 1948. A new prototype ALEXI ET product at $375 \mathrm{~m}$ resolution, generated using day-night LST differences from the Visible Infrared Imaging Radiometer Suite (VIIRS) (the MODIS follow-on instrument) may provide sufficient pure crop pixels for this region. Alternatively, a data fusion system combining ET retrievals from MODIS ( daily, $1 \mathrm{~km}$ resolution) and Landsat (bi-weekly, $30 \mathrm{~m}$ resolution) could be employed to generate ET datasets at daily timesteps and $30 \mathrm{~m}$ resolution (Cammalleri et al. 2013, 2014, Semmens et al. 2016). In practice, a dynamic crop mask would be applied to time-series maps of actualto-reference ET ratio $\left(\mathrm{f}_{\mathrm{RET}}\right)$ at 30 or $375 \mathrm{~m}$ to extract samples of pure pixels for a given crop type. These samples would then reaggregated to the yield monitoring unit (e.g. district level) to produce a localized crop-specific moisture stress function, e.g. of the form as described Doorenbos \& Kassam (1979). A 2 wk to 1 mo $\mathrm{f}_{\mathrm{RET}}$ compositing window would better isolate stress events occurring during moisture-sensitive periods of crop development while still affording some noise reduction capacity. Ongoing research is exploring a combination of high spatiotemporal resolution moisture stress functionals, developed using the data fusion techniques described above, with remotely sensed crop phenology metrics mapped at a similar spatial scale to constrain spatially distributed crop modeling systems of varying complexity (F. Gao et al. unpubl.).

\section{CONCLUSIONS}

This paper investigates drivers of spatial variability in correlations between ESI products, developed at $0.5^{\circ}$ spatial resolution using MODIS retrievals of day-night LST difference, and detrended yield anomalies for spring barley and winter wheat crops grown in several agricultural districts in the CR. For ESI-3 timeseries (3 mo compositing window), correlations for both crops peaked for composite end dates in early-to-mid July, indicating maximum index sensitivity during the April to June period coincid- ing with the spring and summer drought period. Peak correlation coefficients for winter wheat were more variable among districts than for spring barley, resulting from the longer growing season exposure to different yield-limiting climatic events.

The results suggest that ESI will be most beneficial for yield estimation in agricultural districts where crop growth is primarily moisture-limited; in the Czech Republic, these are at lower elevations which are climatologically warmer and drier. Higher resolution ESI products may be of benefit in some of the districts analyzed, to better mask out sub-pixel contributions from ancillary moisture sources in riparian and irrigated areas, and from non-agricultural landcover classes. A prototype ESI product at $375 \mathrm{~m}$ resolution, generated using VIIRS day-night LST differences, will be evaluated for improved performance in these heterogeneous agricultural landscapes.

Future work will compare ESI performance with that of other indices used for routine drought monitoring in the CR (e.g. www.intersucho.cz/en/) based on modeled soil moisture (Hlavinka et al. 2011) and remotely sensed vegetation condition as reflected in NDVI anomalies, and with anomalies in LST which may better capture energy-limiting crop growth conditions at higher elevations. The ultimate goal is to integrate remote sensing indicators conveying moisture and energy constraints within a spatially distributed crop modeling framework that can appropriately apply these constraints during phenologically sensitive stages of crop growth to forecast yield impacts.

Acknowledgements. This work was supported in part by a grant (award no. NNX12AK90G) from the NASA Applied Sciences Program. Authors M.T., P.H., and F.J. acknowledge support from the Ministry of Education, Youth and Sports of the Czech Republic within the National Sustainability Program I (NPU I LO1415) and CzechAdapt project (no. EHPCZ02-OV-1-014-2014). M.T. and P.H. were supported by the National Agency for Agricultural Research (project no. QJ1310123) and F.J. by IGA AF MENDELU project no. IP $14 / 2016$. The USDA is an equal opportunity provider and employer.

\section{LITERATURE CITED}

AghaKouchak A, Nakhjiri N (2012). A near real-time satellite-based global drought climate data record. Environ Res Lett 7:044037

Allen RG, Pereira LS, Raes D, Smith M (1998) Crop evapotranspiration: guidelines for computing crop water requirements. Irrigation and drainage paper 56, FAO, Rome

Anderson MC, Allen RG, Morse A, Kustas WP (2012a). Use of Landsat thermal imagery in monitoring evapotranspi- 
ration and managing water resources. Remote Sens Environ 122:50-65

Anderson MC, Norman JM, Mecikalski JR, Otkin JA, Kustas WP (2007). A climatological study of evapotranspiration and moisture stress across the continental U.S. based on thermal remote sensing. II. Surface moisture climatology. J Geophys Res 112:D11112

- Anderson MC, Hain CR, Wardlow B, Mecikalski JR, Kustas WP (2011) Evaluation of drought indices based on thermal remote sensing of evapotranspiration over the continental US. J Clim 24:2025-2044

Anderson WB, Zaitchik BF, Hain CR, Anderson MC, Yilmaz MT, Mecikalski JR, Schultz L (2012b) Towards an integrated soil moisture drought monitor for East Africa. Hydrol Earth Syst Sci 16:2893-2913

> Anderson MC, Hain CR, Otkin JA, Zhan X and others (2013) An intercomparison of drought indicators based on thermal remote sensing and NLDAS-2 simulations with US drought monitor classifications. J Hydrometeorol 14: 1035-1056

Anderson MC, Zolin C, Hain CR, Semmens KA, Yilmaz MT, Gao F (2015) Comparison of satellite-derived LAI and precipitation anomalies over Brazil with a thermal infrared-based Evaporative Stress Index for 2003-2013. J Hydrol (Amst) 526:287-302

Anderson MC, Zolin C, Sentelhas PC, Hain CR and others (2016) The Evaporative Stress Index as an indicator of agricultural drought in Brazil: an assessment based on crop yield impacts. Remote Sens Environ 174:82-99

Bartholomé E, Belward AS (2005) GLC2000: a new approach to global land cover mapping from Earth observation data. Int J Remote Sens 26:1959-1977

Basso B, Cammarano D, Carfagna E (2013). Review of crop yield forecasting methods and early warning systems. Proceedings of the First Meeting of the Scientific Advisory Committee of the Global Strategy to Improve Agricultural and Rural Statistics. FAO, Rome

$>$ Bastiaanssen WGM, Ali S (2003) A new crop yield forecasting model based on satellite measurements applied across the Indus Basin, Pakistan. Agric Ecosyst Environ 94:321-340

Becker-Reshef I, Vermote E, Lindeman M, Justice CO (2010) A generalized regression-based model for forecasting winter wheat yields in Kansas and Ukraine using MODIS data. Remote Sens Environ 114:1312-1323

Bicheron P, Amberg V, Bourg L, Petit D and others (2011) Geolocation assessment of MERIS GlobCover Orthorectified Products. IEEE T Geosci Remote 49:2972-2982

Bolten JD, Crow WT, Zhan X, Jackson TJ, Reynolds CA (2010) Evaluating the utility of remotely sensed soil moisture retrievals for operational agricultural drought monitoring. IEEE J Sel Top Appl Earth Obs Remote Sens 3: $57-66$

Cammalleri C, Anderson MC, Gao F, Hain CR, Kustas WP (2013) A data fusion approach for mapping daily evapotranspiration at field scale. Water Resour Res 49: 4672-4686

> Cammalleri, C., Anderson, MC, Gao FH, Hain CR, Kustas WP (2014) Mapping daily evapotranspiration at field scales over rainfed and irrigated agricultural areas using remote sensing data fusion. Agric For Meteorol 186:1-11

Doorenbos J, Kassam AH (1979). Yield response to water. Irrigation and drainage paper 33, FAO, Rome

> Doraiswamy PC, Sinclair TR, Hollinger S, Akhmedov B, Stern A, Prueger J (2005) Application of MODIS derived parameters for regional crop yield assessment. Remote Sens Environ 97:192-202

Doraiswamy PC, Akhmedov B, Beard L, Stern A, Mueller R (2007) Operational prediction of crop yields using MODIS data and products. In: Baruth B, Royer A, Genovese G (eds) Proc Int Soc Photogrammetry and Remote Sensing (ISPRS) WG VIII/10 workshop 2006: Remote sensing support to crop yield forecast and area estimates, Nov 30-Dec 1, 2006, Stresa, Italy, p 45-50

> Esquerdo JCDM, Júnior JZ, Antunes JFG (2011) Use of NDVI/AVHRR time-series profiles for soybean crop monitoring in Brazil. Int J Remote Sens 32:3711-3727

Fernandes JL, Rocha JV, Lamparelli R (2011) Sugarcane yield estimates using time series analysis of spot vegetation images. Sci Agric 68:139-146

Friedl M, Sulla-Manashe D, Tan B, Schneider A, Ramankutty N, Sibley AM, Huang X (2010) MODIS Collection 5 global land cover: algorithm refinements and characterization of new datasets. Remote Sens Environ 114: 168-182

Gesch DB, Verdin KL, Greenlee SK (1999) New land surface digital elevation model covers the Earth. Eos Trans AGU 80:69-70

Guan K, Berry J, Zhang Y, Guanter L, Badgley G, Lobell DB (2016) Improving the monitoring of crop productivity using spaceborne solar-induced fluorescence. Glob Change Biol 22:716-26

> Gusso A, Ducati JR, Veronez MR, Arvor D, da Silveira LG Jr (2013) Spectral model for soybean yield estimate using MODIS/EVI Data. Int. J Geosciences 4:1233-1241

Hain CR, Crow WT, Anderson MC, Yilmaz MT (2015) Diagnosing neglected moisture source/sink processes with a thermal infrared-based two-source energy balance model. J Hydrometeorol 16:1070-1086

> Hlavinka P, Trnka M, Semerádová D, Dubrovský M, Žalud Z, Možný M (2009) Effect of drought on yield variability of key crops in Czech Republic. Agric For Meteorol 149: 431-442

Hlavinka P, Trnka M, Balek J, Semerádová D and others (2011) Development and evaluation of the SoilClim model for water balance and soil climate estimates. Agric Water Manage 98:1249-1261

Houborg R, Rodell M, Li B, Reichle RH, Zaitchik BF (2012) Drought indicators based on model-assimilated gravity Recovery and Climate Experiment (GRACE) terrestrial water storage observation. Water Resour Res 48:W07525

Johnson DM (2014) An assessment of pre- and withinseason remotely sensed variables for forecasting corn and soybean yields in the United States. Remote Sens Environ 141:116-128

Kogan FN, Gitelson A, Zakarin E, Spivak L, Lebed L (2003) AVHRR-based spectral vegetation index for quantitative assessment of vegetation state and productivity: calibration and validation. Photogramm Eng Remote Sensing 69:899-906

Kolář P, Trnka M, Brázdil R, Hlavinka P (2014) Influence of climatic factors on the low yields of spring barley and winter wheat in Southern Moravia (Czech Republic) during the 1961-2007 period. Theor Appl Climatol 117: 707-721

Kouadio L, Newlands NK, Davidson A, Zhang Y, Chipanshi A (2014) Assessing the performance of MODIS NDVI and EVI for seasonal crop yield forecasting at the ecodistrict scale. Remote Sens 6:10193-10214

Lobell DB, Ortiz-Monasterio JI, Addams CL, Asner GP 
(2002) Soil, climate, and management impacts on regional wheat productivity in Mexico from remote sensing. Agric For Meteorol 114:31-43

López-Lozano R, Duveiller G, Seguini L, Meroni M and others (2015) Towards regional grain yield forecasting with $1 \mathrm{~km}$-resolution EO biophysical products: strengths and limitations at pan-European level. Agric For Meteorol 206:12-32

Loveland TR, Belward AS (1997) The IGBP-DIS global 1-km land cover data set, DIScover: first results. Int J Remote Sens 18:3289-3295

Mkhabela MS, Mkhabela MS, Mahinini NN (2005) Early maize yield forecasting in the four agro-ecological regions of Swaziland using NDVI data derived from NOAA's-AVHRR. Agric For Meteorol 129:1-9

Mkhabela MS, Bullock P, Raj S, Wang S, Yang Y (2011) Crop yield forecasting on the Canadian Prairies using MODIS NDVI data. Agric For Meteorol 151:385-393

Moran MS (2003). Thermal infrared measurement as an indicator of plant ecosystem health. In: Quattrochi DA, Luvall $\mathrm{J}$ (eds) Thermal remote sensing in land surface processes. Taylor and Francis, Abingdon, p 257-282

Otkin JA, Anderson MC, Hain CR, Mladenova IE, Basara JB, Svoboda M (2013) Examining rapid onset drought development using the thermal infrared based evaporative stress index. J Hydrometeorol 14:1057-1074

> Otkin JA, Anderson MC, Hain CR, Svoboda M (2014) Examining the relationship between drought development and rapid changes in the evaporative stress index. J Hydrometeorol 15:938-956

Otkin JA, Anderson MC, Hain CR, Svoboda M (2015) Using temporal changes in drought indices to generate probabilistic drought intensification forecasts. J Hydrometeorol 16:88-105

Otkin JA, Anderson MC, Hain C, Svoboda M and others

Editorial responsibility: Donald Wilhite,

Lincoln, Nebraska, USA (Guest Editor)
(2016) Assessing the evolution of soil moisture and vegetation conditions during the 2012 United States flash drought. Agric For Meteorol 218-219:230-242

Rembold F, Atzberger C, Savin I, Rojas O (2013) Using low resolution satellite imagery for yield prediction and yield anomaly detection. Remote Sens 5:1704-1733

Rizzi R, Rudorff BFT (2007) MODIS sensor images associated with an agronomic model to estimate soybean grain yield. Pesquisa Agropecu Bras 42:73-80

Semmens KA, Anderson MC, Kustas WP, Gao F and others (2016) Monitoring daily evapotranspiration over two California vineyards using Landsat 8 in a multi-sensor data fusion approach. Remote Sens Environ 185:155-170

Trnka M, Brázdil R, Olesen JE, Eitzinger J and others (2012) Could the changes in regional crop yields be a pointer of climatic change? Agric For Meteorol 166-167:62-71

Trnka M, Brázdil R, Možný M, Štěpánek P and others (2015) Soil moisture trends in the Czech Republic between 1961 and 2012. Int J Climatol 35:3733-3747

Tuanmu MN, Jetz W (2014) A global 1-km consensus landcover product for biodiversity and ecosystem modelling. Glob Ecol Biogeogr 23:1031-1045

Unganai LS, Kogan FN (1998) Southern Africa's recent droughts from space. Adv Space Res 21: 507-511

Wardlow BD, Anderson MC, Verdin JP (eds) (2012) Remote sensing for drought: innovative monitoring approaches. CRC Press/Taylor and Francis, Boca Raton, FL

Zahradníĉek P, Trnka M, Brázdil R, Možný M and others (2015) The extreme drought episode of August 2011May 2012 in the Czech Republic. Int J Climatol 35: 3335-3352

Zhang P, Anderson B, Tan B, Huang D, Myneni RB (2005) Potential monitoring of crop production using a satellitebased Climate-Variability Impact Index. Agric For Meteorol 132:344-358

Submitted: January 28, 2016; Accepted: June 28, 2016 Proofs received from author(s): August 18, 2016 